\title{
Efektivitas Program Pembangunan PSP terhadap Etos Kerja Petani Desa Ngadisuko, Kabupaten Trenggalek, Jawa Timur
}

\section{PSP Development Program's Effectivity Toward Farmer's Working Ethos in Ngadisuko Village, Trenggalek District, East Java}

\author{
Iklil Siffana*), Ugik Romadi, Gunawan
}

Politeknik Pembangunan Pertanian Malang, 0341-427771, 65215, Indonesia

${ }^{*}$ E-mail korespondensi: iklilsiffana@gmail.com

Diterima: 3 Agustus 2020 | Disetujui: 9 Agustus 2021 | Publikasi Online: 23 Agustus 2021

\begin{abstract}
This research focused on the influence of PSP Development Program's (Farming Infrasturcture) toward farmer's working ethos in Ngadisuko village from February to July 2020. This research was focused to examine the effectiveness of the Farming Machineries Program's and Subdisized Fertilizer Program's toward farmer's working ethos. Primary method used in this research are closed quetionaire survey with Likert scale using sample of 90 farmers tested dan regression model test based on Ordinary Least Square method. The result showed that there is significant degree of influence; simultaneously between farming machineries and subsidized fertilizer and effectivity toward farmer's working ethos. However partially inter-variable test showed there is no significant degree of influence toward working ethos and has low influence for 22,5\%. This is due to many problems in the implementation of programs aren't perfect and must be immediately fixed.
\end{abstract}

ABSTRACT

Keywords: Effectivity, farming machineries program, subdisized fertilizer program, working ethos

\section{ABSTRAK}

Penelitian ini mengkaji pengaruh bantuan Program Pembangunan PSP (Prasarana dan Sarana Pertanian) terhadap etos kerja petani di Desa Ngadisuko pada bulan Februari sampai dengan Juni 2020. Fokus penelitian ini untuk mengkaji pengaruh efektivitas program alsintan dan pupuk subsidi terhadap etos kerja petani. Metode yang digunakan dalam penelitian ini adalah penelitian survey dengan kuesioner tertutup menggunakan skala Likert dengan sampel sebanyak 90 orang dan pengujian model regresi menggunakan metode Ordinary Least Square. Hasil penelitian menunjukkan terdapat pengaruh yang signifikan antara variabel efektivitas program pupuk subsidi dan alat mesin pertanian terhadap tingkat etos kerja petani secara simultan. Namun hasil pengujian antar variabel secara parsial menunjukkan tidak adanya pengaruh yang signifikan terhadap etos kerja petani dan diikuti dengan besarnya pengaruh variabel independen sebesar 22,5\% (rendah). Hal ini terjadi karena beberapa permasalahan dalam implementasi progam yang terlaksana belum sempurna dan harus segera dibenahi.

Kata kunci: Efektivitas, etos kerja, program alat mesin pertanian, program pupuk subsidi

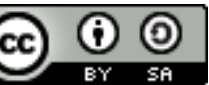

Content from this work may be used under the terms of the Creative Commons Attribution-ShareAlike

4.0 International. Any further distribution of this work must maintain attribution to the author(s) and the title of the work, journal citation and DOI.

Published under Department of Communication and Community Development Science, IPB University and in association with Perhimpunan Ahli Penyuluhan Pembangunan Indonesia.

E-ISSN: 2442-4110 | P-ISSN: 1858-2664 


\section{PENDAHULUAN}

Sektor pertanian dalam Rencana Pembangunan Jangka Menengah Nasional (RPJMN) 2020-2024 merupakan salah satu sektor penting dalam pembangunan nasional. Peran strategis sektor pertanian tersebut terlihat dalam kontribusi nyata sektor pertanian dalam penyedia pangan negeri dan bahan baku industri kecil dan menengah, penyumbang Produk Domestik Bruto dari sektor pertanian sebesar 3,7\% dalam RPJMN 2015-2019. Pada RPJMN 2020-2024 target produktivitas dan pendapatan petani dan nelayan dinaikkan dari 3,7\% menjadi 3,85-3,93\% (Bappenas, 2019b).

Target pencapaian sektor pertanian dalam RPJMN 2020-2024 tentunya dilanjutkan dengan perumusan Rencana Strategis Kementerian (Renstra Kementerian) oleh Kementerian Pertanian beserta jajaran pejabat struktural dan fungsionalnya. Adapun Renstra Kementerian Pertanian yang dirumuskan salah satunya adalah perumusan Visi Kementerian. Visi Kementerian Pertanian periode 2020-2024 yaitu Terwujudnya Kesejahteraan Petani dengan Peningkatan Ketahanan Pangan dan Daya Saing Pertanian (PSP, 2019c). Dengan pedoman dari Renstra Kementerian Pertanian dilanjutkan dengan penyusunan rencana strategis dari beberapa jajaran di bawah Kementerian Pertanian salah satunya perumusan rencana strategis dari Direktorat Jenderal Prasarana dan Sarana Pertanian (PSP, 2019c). Perumusan Rencana Strategis Direktorat Jenderal Prasarana dan Sarana Pertanian (Renstra Ditjen PSP) memuat visi, misi, tujuan, strategi, kebijakan serta program dan kegiatan yang akan dilakukan pada periode 2020-2024. Beberapa misi yang diusung juga dituangkan dalam Program Pembangunan Prasarana dan Sarana Pertanian (Bappenas, 2019a).

Sesuai dengan Visi Kementerian Pertanian yang mengusung tema Kesejahteraan Petani (UU No 11 Tahun 2009, 2009) memaparkan bahwasanya Kesejahteraan Sosial adalah kondisi terpenuhinya kebutuhan material, spiritual, dan sosial warga negara agar dapat hidup layak dan mampu mengembangkan diri sehingga dapat melaksanakan fungsi sosialnya di Indonesia. (BPS RI, 2018) menjelaskan bahwa untuk melihat perkembangan kesejahteraan rakyat suatu wilayah dapat dilihat melalui beberapa indikator yang menjadi ukuran, yaitu: 1) Tingkat kependudukan, 2) Tingkat kesehatan dan gizi penduduk, 3) Tingkat pendidikan, 4) Tingkat ketenagakerjaan, 5) Taraf dan pola konsumsi penduduk, 6) Kondisi perumahan dan lingkungan dalam suatu wilayah, 7) Tingkat kemiskinan penduduk, 8) Tingkat gaya hidup dan pemenuhan kebutuhan sosial penduduk lainnya. Beberapa prasyarat dalam mencapai kesejahteraan petani dapat dicapai apabila kemandirian petani mampu dibentuk dalam diri petani dan pihak luar selaku agen pembaharu seperti penyuluh pendamping yang senantiasa mendampingi petani-petani melakukan kegiatan usaha taninya.

Konsep kemandirian menurut (Sa'diyah, 2017) adalah kondisi individu yang mampu menetapkan dan melakukan aktivitas tanpa bantuan orang lain. Aktivitas yang dimaksud adalah pemenuhan ketiga aspek kebutuhan manusia dalam (UU No 11 Tahun 2009, 2009). (Ginting, 2004) memaparkan bahwa masyarakat mandiri dalam era globalisasi akan dapat tercapai jika didukung oleh transformasi sosialbudaya menuju masyarakat modern. Rasionalitas, kreatifitas, keberanian bersanding, etos kerja yang tinggi, efisiensi dalam berproduksi merupakan nilai-nilai penting secara tekun perlu terus menerus ditumbuhkembangkan dalam masyarakat. Etos kerja dianggap sangat penting karena memuat pandangan dan sikap suatu bangsa yang mendasar terhadap kerja. (Tasmara, 2002) memaparkan bahwa orang-orang yang memiliki etos kerja yang tinggi cenderung menyukai pekerjaannya dan memiliki harapan yang tinggi akan pekerjaan yang ditekuni. Etos kerja juga berhubungan positif dengan produktivitas petani (Iskandar, 2002). Semakin tinggi tingkat etos kerja di kalangan petani, maka semakin tinggi pula tingkat produktivitas petani dalam melakukan usaha taninya. Selain itu, apabila tingkat produktivitas meningkat maka target produktivitas yang telah dirumuskan dalam RPJMN 2020-2024 dapat tercapai.

Makna etos kerja dipandang menjadi sikap dasar yang harus dibentuk dan dikembangkan agar tujuantujuan besar yang disusun perlahan-lahan dapat direalisasikan (Tasmara, 2002). Pemahaman lebih pentingnya makna etos kerja di dalam diri petani harus intensif dilakukan agar mampu menggerakkan petani-petani Indonesia untuk meningkatkan etos kerja dalam dirinya sendiri. Tentunya kegiatan tersebut bukan hal yang mudah karena harus memaksa petani-petani Indonesia keluar dari zona nyamannya sendiri sebagai petani gurem.

Pemberian Bantuan Program Pembangunan PSP (Prasarana dan Sarana Pertanian) dilakukan dengan tujuan langsung yaitu mampu meningkatkan intensifikasi serta ekstensifikasi pertanian di Indonesia dalam (PSP, 2019a). Selain itu apakah dengan adanya Program Pembangunan PSP mampu 
mempengaruhi aspek intrinsik dalam diri petani seperti semangat dalam mengerjakan usaha taninya, senantiasa mampu menghadapi berbagai tantangan baru dan lebih percaya diri akan usaha agribisnis yang telah dijalankannya sampai saat ini. Beberapa aspek tersebut merupakan indikator-indikator dalam etos kerja.

Berdasarkan pertimbangan-pertimbangan diatas, penelitian ini dilakukan untuk mengetahui pengaruh efektivitas Program Pembangunan PSP terhadap etos kerja petani Desa Ngadisuko, Kecamatan Durenan, Kabupaten Trenggalek. Penelitian ini dianggap penting karena peneliti mengkaji apakah etos kerja dapat dipengaruhi dari aspek eksternal yaitu Program Pembangunan PSP. Sedangkan beberapa penelitian terdahulu lebih banyak menempatkan variabel etos kerja sebagai variabel independen yang menunjukkan indikasi bahwasanya etos kerja pada individu dapat memengaruhi banyak aspek terkait keberlanjutan individu dalam menjalankan kehidupannya sebagai manusia. Aspek-aspek tersebut adalah tingkat produktivitas petani (Iskandar, 2002), kinerja pegawai (Karauwan \& Mintardjo, 2015), hingga pada upaya penanggulangan krisis pangan (Perdana, 2013).

Batasan jenis Program Pembangunan PSP yang dipilih peneliti adalah Program Pupuk Subsidi dan Program Alat Mesin Pertanian. Program pupuk subsidi dipilih karena terdapatnya perombakan mekanisme pengajuan pupuk subsidi di Desa Ngadisuko dari perumusan Rencana Definitif Kebutuhan Kelompok (RDKK) secara manual berubah menjadi berbasis online dalam bentuk e-RDKK dan diintegrasikan penggunaan Kartu Tani dalam penebusan pupuk subsidi pada Tahun 2018. Hal ini juga sesuai dengan penelitian (Jorgi et al., 2019) yang memaparkan bahwa pelaksanaan program Kartu Tani di Provinsi Jawa Tengah telah dirumuskan sejak tahun 2016 namun serentak dilakukan pada Tahun 2018.

Program Alat Mesin Pertanian juga dipilih karena mulai Tahun 2019, semua bantuan alat mesin pertanian diarahkan dengan tujuan penumbuhan Unit Pelayanan Jasa Alsintan (UPJA) di setiap daerah penerima bantuan alsintan yang sebelumnya hanya ditujukan pada pemenuhan kebutuhan petani. Hal ini juga sesuai dengan penelitian (Purwantini \& Susilowati, 2018) yang memaparkan bahwa pemberian bantuan alat mesin pertanian terhadap UPJA telah dilakukan sejak tahun 2015 untuk bantuan traktor roda 2 , traktor roda 4 , pompa air dan rice transplanter, sedangkan penyaluran bantuan combine harvester mulai dilakukan pada Tahun 2016.

Adanya beberapa pembaruan pada Program Pembangunan PSP yang dipilih oleh peneliti memberikan penjelasan bahwa mekanisme penyaluran Program Pembangunan PSP dilakukan beberapa penyempurnaan agar lebih memudahkan semua pihak dalam pemanfaatan Program Pembangunan PSP di Indonesia. Selain itu juga memunculkan indikasi bahwa beberapa program tersebut kedepannya mendapat pemantauan secara khusus dan terbentuk beberapa penyempurnaan baru di kemudian hari.

\section{METODE PENELITIAN}

Lokasi penelitian yang ditetapkan pada penelitian ini berada di Desa Ngadisuko, Kecamatan Durenan, Kabupaten Trenggalek. Penentuan lokasi penelitian dilakukan dengan beberapa pertimbangan, yaitu: Pertama, petani di Desa Ngadisuko termasuk petani yang aktif dan maju terbukti dari banyaknya bantuan alat mesin pertanian yang tidak hanya turun dari pemerintah melainkan dari pihak di luar pemerintah seperti partai.

Kedua, kondisi penduduk Desa Ngadisuko yang jarang terlibat konflik antar warga membuat kerukunan antar warga terjalin sempurna, dan sangat terbuka ketika mengetahui petani-petani di Desa Ngadisuko dijadikan sasaran dalam penelitian.

Ketiga, kondisi Gapoktan yang mendapatkan pendampingan dari Dinas Pertanian dan Pangan Trenggalek untuk membentuk Kelembagaan Ekonomi Petani (KEP) dan masih dalam proses pengajuan dan pembinaan intensif. Hal itu dapat terjadi karena gapoktan mampu mengembangkan bantuan dana Pengembangan Usaha Agribisnis Pertanian (PUAP) menjadi Lembaga Keuangan Mikro Agribisnis (LKM-A) dengan pesat dan terbebas dari permasalahan utang piutang terhadap anggota. Tentunya keberhasilan pengembangan gapoktan menjadi Kelembagaan Ekonomi Petani tidak jauh dari support anggota untuk senantiasa disiplin dan taat aturan dalam proses peminjaman dana di LKM-A Gapoktan Desa Ngadisuko.

Populasi yang digunakan dalam penelitian ini adalah petani yang tergabung dalam kelompok tani Desa Ngadisuko Kecamatan Durenan Kabupaten Trenggalek. Desa Ngadisuko memiliki 4 kelompok tani yaitu: 1) Kelompok Tani Langgeng Jaya dengan anggota sebanyak 270 orang, 2) Kelompok Tani Adi 
Luwih dengan anggota sebanyak 256 orang, 3) Kelompok Tani Ngudi Mulyo dengan anggota sebanyak 137 orang, 4) Kelompok Tani Sumber Rejeki dengan anggota sebanyak 212 orang. Dari pemaparan tersebut dapat diketahui bahwasanya jumlah populasi dalam penelitian ini sebayak 875 orang.

Pengambilan sampel yang dipilih menggunakan simple random sampling dengan melalui perhitungan Slovin yang menggunakan taraf kesalahan sebesar $10 \%$. Perhitungan tersebut memberikan nilai sebesar 89,7 orang atau dibulatkan menjadi 90 orang. Jumlah sampel tersebut selanjutnya dibagi lagi menggunakan teknik proportional random sampling dengan alasan agar sampel ditentukan secara proporsional dan mampu mewakili masing-masing kelompok tani yang ada di Desa Ngadisuko dengan rincian 1) Kelompok Tani Langgeng Jaya sebanyak 28 orang, 2) Kelompok Tani Adi Luwih sebanyak 26 orang, 3) Kelompok Tani Ngudi Mulyo sebanyak 14 orang, 4) Kelompok Tani Sumber Rejeki sebanyak 22 orang.

Metode kajian yang ditetapkan dalam penelitian ini adalah penelitian kuantitatif dengan metode survey dengan teknik pengumpulan data yang dilakukan diawali pengamatan keadaan lingkungan untuk mengambil data sementara, dilanjutkan dengan pembagian instrumen kuesioner menggunakan skala likert dengan kategori. Teknik wawancara juga dilakukan untuk memverifikasi kembali terkait kebenaran data yang dituangkan dalam hasil kuesioner. Selain itu kegiatan studi dokumentasi dilakukan peneliti untuk mengumpulkan dokumen yang terkait dengan topik penelitian.

Variabel yang digunakan dalam penelitian ini adalah variabel bebas dan variabel terikat. Penelitian ini menggunakan 2 variabel bebas yaitu variabel efektivitas program alsintan dan pupuk subsidi yang keduanya memiliki indikator pengukuran efektivitas yang sama meliputi 1) Tepat kebijakan, 2) Tepat pelaksanaan, 3) Tepat target, 4) Tepat lingkungan (Nugroho, 2008). Sedangkan, variabel terikat dalam penelitian ini adalah etos kerja petani yang diukur dengan beberapa indikator diantaranya 1) Kerja adalah rahmat, 2) Kerja adalah amanah, 3) Kerja adalah panggilan, 4) Kerja adalah aktualisasi, 5) Kerja adalah ibadah, 6) Kerja adalah seni, 7) Kerja adalah kehormatan, 8) Kerja adalah pelayanan (Sinamo, 2011). Detail variabel yang digunakan dalam penelitian ini dapat dilihat dalam Tabel 1.

Tabel 1. Variabel, sub variabel dan indikator dalam penelitian

\begin{tabular}{|c|c|c|}
\hline Variabel & Sub Variabel & Indikator \\
\hline \multirow{4}{*}{$\begin{array}{l}\text { Efektivitas } \\
\text { Program Alat } \\
\text { Mesin } \\
\text { Pertanian (X1) }\end{array}$} & Tepat Kebijakan & $\begin{array}{l}\text { Bantuan alsintan yang turun sesuai dengan kebutuhan } \\
\text { petani }\end{array}$ \\
\hline & Tepat Pelaksanaan & $\begin{array}{l}\text { Petani penerima bantuan alsintan adalah petani yang } \\
\text { masuk dalam daftar penerima bantuan }\end{array}$ \\
\hline & Tepat Target & $\begin{array}{l}\text { Kelompok tani penerima bantuan alsintan merupakan } \\
\text { kelompok tani yang memiliki keanggotaan aktif }\end{array}$ \\
\hline & Tepat Lingkungan & $\begin{array}{l}\text { Proses monitoring bantuan alsintan dilakukan secara rutin } \\
\text { dan mendapat persepsi positif dari penerima bantuan }\end{array}$ \\
\hline \multirow{4}{*}{$\begin{array}{l}\text { Efektivitas } \\
\text { Program } \\
\text { Pupuk } \\
\text { Bersubsidi } \\
\text { (X2) }\end{array}$} & Tepat Kebijakan & $\begin{array}{l}\text { Bantuan pupuk subsidi yang turun sesuai dengan jumlah } \\
\text { dan jenis kebutuhan pupuk di lapangan }\end{array}$ \\
\hline & Tepat Pelaksanaan & $\begin{array}{l}\text { Waktu penebusan pupuk subsidi dilakukan tepat sebelum } \\
\text { masa tanam }\end{array}$ \\
\hline & Tepat Target & $\begin{array}{l}\text { Petani penerima bantuan pupuk subsidi merupakan petani } \\
\text { yang terdaftar dalam e-RDKK dan memiliki Kartu Tani }\end{array}$ \\
\hline & Tepat Lingkungan & $\begin{array}{l}\text { Proses monitoring bantuan pupuk subsidi dilakukan secara } \\
\text { rutin dan mendapat persepsi positif dari penerima bantuan }\end{array}$ \\
\hline \multirow{6}{*}{ Etos Kerja $(\mathrm{Y})$} & Kerja adalah rahmat & Petani senantiasa bersyukur atas pekerjaan ia emban \\
\hline & Kerja adalah amanah & $\begin{array}{l}\text { Petani memiliki sifat tanggung jawab dalam melakukan } \\
\text { pekerjaannya }\end{array}$ \\
\hline & Kerja adalah panggilan & $\begin{array}{l}\text { Bekerja dianggap sebagai panggilan dari Tuhan dan } \\
\text { merupakan tugas suci }\end{array}$ \\
\hline & $\begin{array}{l}\text { Kerja adalah } \\
\text { aktualisasi }\end{array}$ & $\begin{array}{l}\text { Petani senantiasa mengakses informasi baru guna } \\
\text { pengembangan potensi yang ada dalam dirinya }\end{array}$ \\
\hline & Kerja adalah ibadah & $\begin{array}{l}\text { Bekerja sebagai petani adalah bentuk ibadah kepada } \\
\text { Tuhan YME }\end{array}$ \\
\hline & Kerja adalah seni & Petani mengadopsi semua inovasi pertanian terbaru di \\
\hline
\end{tabular}




\begin{tabular}{lll}
\hline Variabel & \multicolumn{1}{c}{ Sub Variabel } & \multicolumn{2}{c}{ Indikator } \\
\hline & Kerja adalah & lahannya \\
kehormatan & $\begin{array}{l}\text { Petani memiliki sikap tekun dan hormat atas } \\
\text { pekerjaannya } \\
\text { Kerja adalah pelayanan }\end{array}$ & $\begin{array}{l}\text { Petani memiliki rasa bahagia apabila hasil usaha taninya } \\
\text { mendapat respon positif dari pelanggan }\end{array}$ \\
\hline
\end{tabular}

Teknik pengujian instrumen dilakukan menggunakan uji validitas dan reliabilitas dengan tujuan data yang disajikan merupakan data yang handal. Adapun model regresi diuji dengan menggunakan metode Metode Ordinary Least Square (OLS) dengan dua variabel independen (variabel Efektivitas Program Alsintan $/ \mathrm{X}_{1}$ dan variabel Efektivitas Program Pupuk Subsidi/ $\mathrm{X}_{2}$ ) dan satu variabel dependen (Etos Kerja Petani/Y). Pengujian hipotesis dilakukan dengan melakukan uji statistik $\mathrm{t}$ dan uji $\mathrm{F}$ dilanjutkan dengan melihat nilai koefisien determinasi $\left(\mathrm{R}^{2}\right)$ untuk mengetahui besarnya pengaruh variabel independen terhadap variabel dependen pada proporsi yang sama. Adapun untuk pengujian instrumen dan model regresi dilakukan menggunakan software Statistical Package for the Social Sciences (SPSS) 20. Hipotesis dalam penelitian ini diduga terdapat pengaruh antara variabel efektivitas program pupuk bersubsidi dan program alat mesin pertanian terhadap tingkat etos kerja petani $\left(\mathrm{H}_{1}\right)$.

\section{HASIL DAN PEMBAHASAN}

Desa Ngadisuko merupakan salah satu dari 14 desa di wilayah Kecamatan Durenan yang berada pada koordinat 8,1306 Lintang Selatan dan 111,7951 Bujur Timur dengan jarak kantor desa ke kantor kecamatan sejauh 1,2 km dan jarak kantor desa ke kantor kabupaten sejauh 17,3 km. Luas wilayah Desa Ngadisuko adalah 303,113 hektar dengan ketinggian tempat dari pemukaan laut yaitu 96 mdpl dengan topograri wilayah berupa dataran (BPS, 2019). Tanah di Desa Ngadisuko berbentu abu vulkanik sehingga jenis tanahnya mayoritas didominasi ordo tanah entisol. Karakteristik agroekologi wilayah Desa Ngadisuko yaitu ordo tanah Entisol (tanah regosol, alluvial pasir dan litosol), kebasahan ustik ( $>4$ bulan kering per tahun), temperatur isohyperthemic $\left(>22^{\circ} \mathrm{C}\right)$, fisiografi datar landai yang terbagi antara 30\% lahan kering dan $70 \%$ lahan sawah. Keadaan iklim berdasarkan rata-rata curah hujan basah 5 bulan dan bulan kering <8 bulan, dengan curah hujan $1.447 \mathrm{~mm} / \mathrm{th}$ dam tipe iklim C4 / Oldemen (BPS, 2019).

Jumlah penduduk di Desa Ngadisuko sebanyak 5.582 jiwa dengan pembagian penduduk laki-laki 2.734 jiwa dan penduduk perempuan sebanyak 2.848 jiwa yang terbagi dalam 36 rukun tetangga (RT), 4 rukun warga (RW) dan 3 dusun. Penduduk Desa Ngadisuko didominasi oleh penduduk dengan lulusan SD sederajat yaitu sebesar 32,38\% disusul dengan lulusan SLTA sederajat yaitu sebesar $19,04 \%$. Pekerjaan penduduk Desa Ngadisuko didominasi oleh pekerjaan wiraswasta sebanyak 1.204 jiwa, pelajar/mahasiswa sebanyak 1.017 jiwa kemudian petani/pekebun sebanyak 780 jiwa. Pekerjaan buruh tani/perkebunan sebanyak 27 jiwa menempati peringkat ke 9 dari jumlah penduduk berdasarkan pekerjaan. Hal ini membuktikan bahwa pekerjaan di sektor pertanian masih ditekuni oleh beberapa penduduk di Desa Ngadisuko.

Desa Ngadisuko memiliki luas wilayah 303,113 hektar yang berpotensi menjadi sawah sebesar 163 hektar, tegal sebesar 5,5 hektar, pekarangan sebesar 133,5 hektar, dan lain-lain sebesar 1,113 hektar. Adapun irigasi setengah teknis sebesar 15 hektar. Pembagian pola tanam lahan di Desa Ngadisuko dibagi menjadi lahan peruntukan sawah, tegal dan pekarangan yang biasa ditanami padi sawah, palawija, tanaman sayuran, buah-buahan dan obat-obatan.

Deskripsi kondisi umum implementasi Program Pembangunan Prasarana dan Sarana Pertanian diawali dengan deskripsi kondisi implementasi program pupuk subsidi. Pupuk subsidi adalah barang dalam pengawasan yang pengadaan dan penyalurannya mendapat subsidi dari Pemerintah untuk kebutuhan petani di sektor pertanian. Desa Ngadisuko bertahun-tahun telah mendapatkan pupuk bersubsidi melalui Rencana Definitif Kebutuhan Kelompok Tani (RDKK).

Mekanisme pengajuan RDKK di Desa Ngadisuko adalah melalui rembug tani yang dihadiri oleh semua kelompok tani Desa Ngadisuko dan kepala desa serta penyuluh pendamping. Setelah rembug tani selesai dilaksanakan dan seluruh data petani yang telah di data dalam form RDKK maka pengajuan RDKK dapat dilanjutkan pada tingkat kecamatan, kabupaten dan pusat. Namun pada tahun 
2017 Desa Ngadisuko telah mendapatkan sosialisasi untuk mekanisme perombakan pengajuan eRDKK menjadi e-RDKK atau Elektronik Rencana Definitif Kebutuhan Kelompok Tani. Dilanjutkan pada tahun 2018 perlahan-lahan mulai dilakukannya perombakan pengajuan pupuk subsidi melalui upload ke website e-RDKK yang mekanisme pengajuan ke pusat lebih cepat. Penyusunan pengajuan pupuk subsidi dilakukan pada awal tahun dengan mencakup telah mencakup rencana kebutuhan pupuk selama 3 kali musim tanam. Selanjutnya pupuk yang turun berkala pada saat menjelang musim tanam. Desa Ngadisuko juga mendapat Program bantuan alat mesin pertanian yang berhasil turun dalam lingkup Kecamatan Durenan per tahun 2015-2018 telah berhasil menurunkan jenis alat mesin pertanian diantaranya traktor roda 4 , rice transplanter, hand sprayer, corn planter, combain harvester kecil, pompa air, dan traktor roda 2.

Mekanisme penyaluran bantuan alat mesin pertanian dimulai dari pengajuan proposal oleh kelompok tani. Adapun konten dalam proposal kelompok tani yang dibahas meliputi kondisi kelompok tani dan desa secara umum dan alasan pengajuan bantuan alat mesin pertanian yang dimaksud. Dalam pengajuan proposal juga melalui proses persetujuan dari ketua kelompok tani, mantri tani, kepala dinas dan pangan kabupaten. Selain proses pengajuan proposal ke Kementerian Pertanian, pengajuan bantuan alat mesin pertanian dapat melalui partai tetapi tetap menggunakan proposal pengajuan terlebih dahulu.

Setelah proposal sudah sampai kepada yang dituju selanjutnya pemohon menunggu SK turun dari pusat dan tidak semua pengajuan proposal dapat turun. Bantuan alat mesin pertanian yang berhasil sebelumnya melalui pertimbangan-pertimbangan dari pusat yang peneliti tidak ketahui mekanismenya. Bantuan alat mesin pertanian yang turun selanjutnya dapat diambil oleh pewakilan kelompok tani. Perawatan bantuan alat mesin yang turun selanjutnya diserahkan pada kelompok tani masing-masing dan melakukan pelaporan penggunaan secara berkala.

Karakteristik responden dalam penelitian ini diawali dengan pembahasan mengenai umur responden. Umur responden pada penelitian ini didominasi pada responden yang berusia produktif sebesar 69\% sesuai dengan (UU No 13 Tahun 2003, 2003) memaparkan bahwa seseorang dikatakan masuk pada lingkup usia produktif apabila berada pada rentang usia antara 1-64 tahun. Petani yang memiliki umur produktif memiliki fisik yang lebih kuat jika dibandingkan dengan petani yang sudah tidak produktif. Apabila umur individu telah melewati rentang usia produktif maka bisa dipastikan kekuatan fisiknya juga menurun (Dwiandana Putri \& Setiawina, 2013).

Pembagian responden berdasarkan tingkat Pendidikan memberikan informasi mengenai pendidikan terakhir yg dienyam oleh responden berada pada kisaran tingkat pendidikan terakhir. Rata-rata tingkat Pendidikan responden berasal pada lingkup Pendidikan SD tahun yang menunjukkan bahwa responden dalam penelitian tergolong ke dalam kategori tingkat Pendidikan yang rendah. (Todaro, 1994) memaparkan bahwa pendidikan dapat menjadi kunci untuk membentuk kemampuan negara berkembang untuk mengadopsi teknologi modern dalam pengembangan pembangunan yang berkelanjutan. Hal ini menunjukkan masih banyak petani yang memiliki tingkat kemampuan adopsi teknologi yang masih rendah.

Lahan pertanian merupakan salah satu faktor yang memengaruhi jumlah produksi. Semakin luas lahan yang diolah, berdampak pada semakin banyaknya produksi yang dihasilkan oleh lahan. Namun pengaruh luas lahan juga berdampak pada upaya penerapan teknologi pada pembangunan pertanian kedepannya (Andrias et al., 2017). Distribusi responden berdasarkan luas lahan mayoritas berada di rentang luas lahan antara $0-0,25$ hektar. Hal ini menunjukkan bahwa luasan lahan yang dimiliki petani tergolong pada petakan yang sempit dan pemilihan teknologi pertanian kedepan tentunya juga mengacu pada penerapan teknologi pertanian yang berdaya guna di lahan yang sempit. Upaya ini perlu mendapatkan perhatian khusus dari pihak luar untuk memberikan teknologi yang dapat diterapkan oleh petani.

Pengujian model regresi diawali dengan uji validitas dan reliabilitas instrumen. Pengujian tersebut dilakukan dengan tujuan untuk mengetahui apakah butir pertanyaan yang tertuang pada kuesioner telah dinyatakan layak dan reliabel dalam menjelaskan indikator-indikator pada penelitian. Adapun hasil uji validitas dan reliabilitas dipaparkan sebagai berikut: 


\section{Validitas Instrumen}

Uji validitas dilakukan untuk mengetahui kelayakan butir pertanyaan dalam kuesioner penelitian untuk mendefinisikan sebuah variabel tertentu. Daftar pertanyaan yang disusun biasanya terdiri dari lebih dari satu pertanyaan yang bertujuan untuk membuktikan sebuah variabel (Sujarweni, 2015). Uji validitas instrumen penelitian dilakukan pada populasi petani yang tergabung dalam kelompok tani Desa Ngadisuko diluar sampel penelitian. Jumlah petani yang diambil dalam kegiatan ini sebanyak 30 orang. Validitas instrumen dikatakan valid dimana $\mathrm{df}=\mathrm{n}-2$ dengan taraf signifikansi sebesar $5 \%$ apabila nilai dalam setiap butir pertanyaan memiliki nilai $r_{\text {hitung }}>r_{\text {tabel }}$.

Uji validitas instrumen memberikan hasil bahwa item nomor 23, 27 dan 31 tidak valid dikarenakan nilai $r_{\text {hitung }}<r_{\text {tabel }}(0,361)$. Selanjutnya dapat dilakukan uji reliabilitas instrumen penelitian.

\section{Reliabilitas Instrumen}

Uji reliabilitas dilakukan untuk mengetahui konsistensi responden dalam menjawab butir-butir pertanyaan dalam kuesioner yang merupakan indikator dalam suatu variabel tertentu. Kuesioner dikatakan variabel apabila nilai alpha $>0,60$ (Sujarweni, 2015). Hasil uji reliabilitas kuesioner penelitian dipaparkan pada Tabel 2.

Tabel 2. Hasil uji reliabilitas instrumen penelitian

\begin{tabular}{lc}
\hline \multicolumn{2}{c}{ Reliability Statistics } \\
\hline Cronbach's Alpha & N of Items \\
\hline .884 & 28 \\
\hline
\end{tabular}

Hasil uji reliabilitas memberikan nilai Cronbach's Alpha sebesar 0,884 dimana instrumen penelitian dikatakan konsisten / reliabel dikarenakan nilai Cronbach's Alpha lebih dari 0,60. Setelah instrumen dinyatakan layak dan reliabel maka dapat dilanjutkan dengan pengujian model regresi dengan Metode Ordinary Least Square (OLS). Adapun hasil pengujian model regresi dipaparkan sebagai berikut:

\section{Uji Asumsi Klasik}

\section{Uji Normalitas}

Uji normalitas bertujuan untuk mengetahui distribusi data dalam variabel yang akan digunakan dalam penelitian. Data yang layak adalah data yang memiliki distribusi data yang normal (Sujarweni, 2015). Data dikatakan normal dengan cara melihat dari chart normal probability plot yang membandingkan distribusi kumulatif dan distribusi normal (Ghozali, 2011). Hasil chart normal probability plot yang keluar di SPSS disajikan pada Gambar 1.

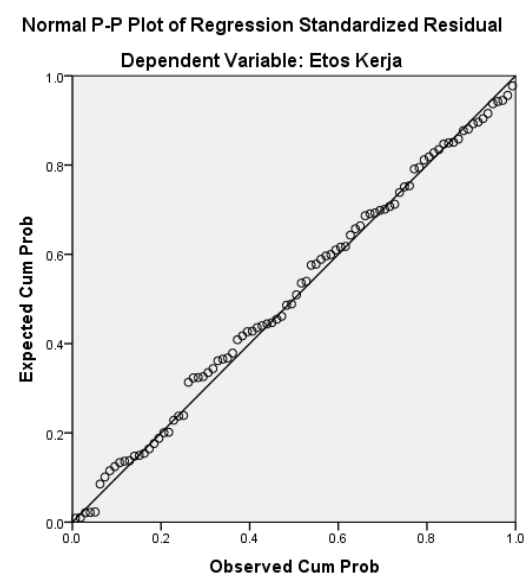

Gambar 1. Chart Normal P-P Plot

Gambar 1 menunjukkan bahwa grafik normal probability plot berada pada pola grafik yang normal. Pola tersebut menunjukkan titik yang menyebar di sekitar grafik normal atau diagonal. Hal ini sesuai dengan dasar pengambilan keputusan pada analisis grafik dengan chart normal probability plot adalah jika data menyebar di sekitar garis diagonal dan mengikuti arah garis normal maka data dapat 
dikatakan normal. Sedangkan, jika data menyebar jauh dari garis diagonal dan atau tidak mengikuti arah garis diagonal maka data dikatakan tidak normal (Ghozali, 2011). Oleh karena itu, dapat disimpulkan bahwa model regresi ini layak digunakan karena memenuhi asumsi uji normalitas.

\section{Uji Multikolinearitas}

Uji multikolinearitas dilakukan untuk mengetahui apakah terdapat variabel independen yang memiliki kemiripan antar variabel independen dalam suatu model (Sujarweni, 2015). Hasil uji multikolinearitas disajikan pada Tabel 3.

Tabel 3. Uji multikolinearitas

\begin{tabular}{llcc}
\hline \multicolumn{1}{c}{ Model } & \multicolumn{2}{c}{ Collinearity Statistics } \\
\cline { 3 - 4 } & & Tolerance & VIF \\
\hline 1 & (Constant) & .885 & 1.130 \\
Tepat Kebijakan Program Alsintan & .917 & 1.090 \\
Tepat Pelaksanaan Program Alsintan & .674 & 1.484 \\
Tepat Target Program Alsintan & .656 & 1.525 \\
Tepat Lingkungan Program Alsintan & .828 & 1.208 \\
Tepat Kebijakan Program Pupuk Subsidi & .836 & 1.196 \\
Tepat Pelaksanaan Program Pupuk Subsidi & .773 & 1.294 \\
Tepat Target Program Pupuk Subsidi & .719 & 1.390 \\
Tepat Lingkungan Program Pupuk Subsidi & & \\
\hline
\end{tabular}

a. Dependent Variable: Etos Kerja

Pada Tabel 3 dapat dilihat bahwa model regresi tidak mengalami kondisi multikolinearitas. Hal ini terlihat pada nilai VIF yang menunjukkan nilai pada masing-masing variabel tidak lebih dari 10 . Hal ini sesuai dengan Dasar pengambilan keputusan dalam uji multikolinearitas adalah apabila nilai VIF yang keluar pada output uji multikolinearitas menunjukkan nilai diantara nilai 1-10 maka data dinyatakan tidak terjadi multikolinearitas (Sujarweni, 2015).

\section{Uji Heteroskedastisitas}

Uji keteroskedastisitas dilakukan untuk menguji terjadinya perbedaan variance residual suatu periode pengamatan ke periode pengamatan yang lain. Cara melihat ada tidaknya heteroskedastisitas salah satunya dengan Uji Glejser (Sujarweni, 2015). Uji Glejser dilakukan dengan cara meregresikan nilai absolut residual pada data terhadap variabel independen. Hasil uji heteroskedastisitas dapat dilihat pada Gambar 2.

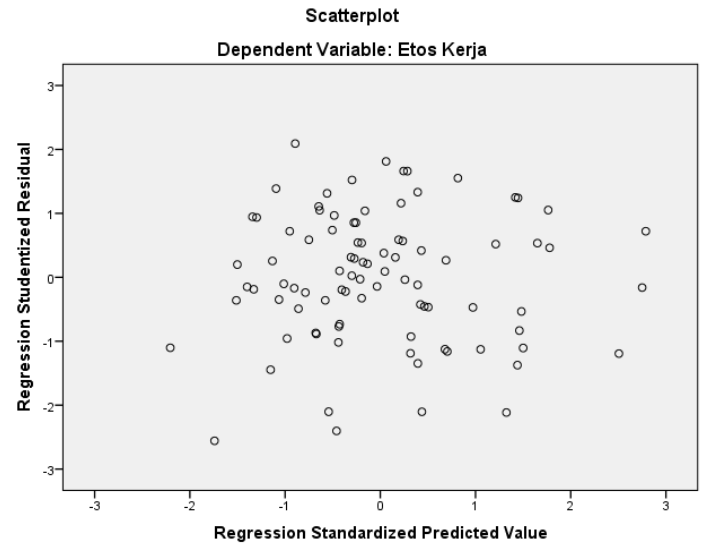

Gambar 2. Grafik Scatterplot

Gambar 2 dapat dilihat bahwa titik-titik pada grafik scatterplot memiliki penyebaran yang tidak berpola, dan tersebar pada rang angka diatas dan di bawah nilai 0. Hal ini sesuai dengan dasar pengambilan keputusan dalam uji ini adalah jika terdapat pola tertentu seperti titik-titik yang membentuk sebuah pola yang teratur maka dapat dikatakan model regresi mengalami heteroskedastisitas. Sebaliknya, jika tidak ada pola yang tergambar jelas pada gambar dan titik-titik 
menyebar diatas dan di bawah angka 0 maka dapat dikatakan model regresi tidak mengalami heteroskedastisitas (Ghozali, 2011). Maka dapat disimpulkan bahwa model regresi tidak terdapat gangguan heteroskedastisitas.

\section{Uji Autokorelasi}

Uji Autokorelasi digunakan untuk mengetahui pada model regresi linear apakah ada korelasi antara kesalahan pengganggu pada periode $\mathrm{t}$ dengan kesalahan pengganggu pada periode $\mathrm{t}-1$. Dalam uji autokorelasi apabila terjadi korelasi, maka dinamakan ada masalah atau problem autokorelasi. Untuk menguji ada atau tidak gejala autokorelasi, digunakan uji Runs Test (Ghozali, 2011).

Dasar pengambilan keputusan dalam Uji Run Test yaitu apabila nilai Asym: Sig. (2-tailed) lebih kecil dari 0,05 maka terdapat gejala autokorelasi dan sebaliknya, jika nilai Asym: Sig. (2-tailed) lebih besar dari 0,05 maka tidak terdapat gejala autokorelasi (Ghozali, 2011). Hasil Uji Runs Test pada software SPSS dipaparkan pada Tabel 4.

Tabel 4. Uji autokorelasi

\section{Runs Test}

Unstandardized Residual

\begin{tabular}{lr}
\hline Test Value $^{\mathrm{a}}$ & -.00940 \\
Cases $<$ Test Value & 45 \\
Cases $>=$ Test Value & 45 \\
Total Cases & 90 \\
Number of Runs & 39 \\
Z & -1.484 \\
Asymp. Sig. (2-tailed) & .138 \\
\hline
\end{tabular}

Median

Berdasarkan output SPSS diatas, diketahui nilai Asymp Sig. (2-tailed) sebesar 0,138 yang mana nilai tersebut lebih besar dari 0,05 sehingga dapat disimpulkan bahwa model regresi tidak terjadi masalah autokorelasi. Dengan demikian, gejala autokorelasi yang tidak dapat terselesaikan dengan uji Durbin Watson dapat teratasi melalui uji run test sehingga pada rangkaian terakhir uji asumsi klasik ini menunjukkan bahwa model regresi layak digunakan dan dapat dilanjutkan ke tahap analisis berikutnya.

\section{Uji Kelayakan Model Regresi}

\section{Uji Statistik F}

Uji $\mathrm{F}$ digunakan untuk mengetahui apakah efektivitas program pupuk bersubsidi dan program alat mesin pertanian secara bersama-sama berpengaruh signifikan terhadap tingkat etos kerja petani. Dasar pengambilan keputusan adalah jika nilai sig $<0,05$ maka $\mathrm{H}_{0}$ ditolak pada taraf kepercayaan $5 \%$ dan $\mathrm{H}_{1}$ diterima. Kemudian dasar pengambilan keputusan juga dapat diambil dengan membandingkan nilai $\mathrm{F}_{\text {hitung }}$ dengan $\mathrm{F}_{\text {tabel. }}$. Jika nilai $\mathrm{F}_{\text {hitung }}>\mathrm{F}_{\text {tabel }}$ maka $\mathrm{H}_{0}$ ditolak dan $\mathrm{H}_{1}$ diterima (Sujarweni, 2015). Hasil Uji Statistik F melalui pengolahan SPSS dapat dilihat pada Tabel 5.

Tabel 5. Uji statistik F

\begin{tabular}{|c|c|c|c|c|c|c|}
\hline \multicolumn{7}{|c|}{ ANOVA $^{a}$} \\
\hline Model & & $\begin{array}{l}\text { Sum of } \\
\text { Squares }\end{array}$ & df & $\begin{array}{l}\text { Mean } \\
\text { Square }\end{array}$ & $\mathrm{F}$ & Sig. \\
\hline \multirow[t]{3}{*}{1} & Regression & 422.335 & 8 & 52.792 & 3.874 & $.001^{\mathrm{b}}$ \\
\hline & Residual & 1103.765 & 81 & 13.627 & & \\
\hline & Total & 1526.100 & 89 & & & \\
\hline
\end{tabular}

a. Dependent Variable: Etos Kerja

b. Predictors: (Constant), Tepat Lingkungan Program Pupuk Subsidi, Tepat Target Program Pupuk Subsidi, Tepat Kebijakan Program Alsintan, Tepat Pelaksanaan Program Alsintan, Tepat Pelaksanaan Program Pupuk Subsidi, Tepat Kebijakan Program Pupuk Subsidi, Tepat Target Program Alsintan, Tepat Lingkungan Program Alsintan

Pada Tabel 5 dapat dilihat bahwa nilai signifikansi menunjukkan angka $0,000(0,00<0,05)$. Kemudian nilai $\mathrm{F}_{\text {hitung }}$ sebesar 3,874 $(3,874>3,11)$ yang artinya $\mathrm{H}_{0}$ ditolak dan $\mathrm{H}_{1}$ diterima. Pernyataan tersebut 
memberikan kesimpulan bahwa variabel efektivitas program pupuk bersubsidi dan program alat mesin pertanian secara bersamaan (simultan) memiliki pengaruh terhadap etos kerja petani.

Hasil uji statistik F memberikan hasil bahwa variabel bahwa variabel efektivitas program pupuk bersubsidi dan program alat mesin pertanian secara simultan memiliki pengaruh terhadap etos kerja petani. Hasil penelitian ini dapat dibuktikan bahwa salah satu aspek pengukuran dalam etos kerja menurut (Probowati, 2008) adalah timbulnya minat dari individu untuk memenuhi kebutuhan biologisnya. Dilanjutkan dengan faktor-faktor yang mampu memengaruhi minat seseorang menurut salah satunya dari faktor eksternal (Suharyat, 2009). Aspek eksternal juga mampu memengaruhi minat seseorang yang terbagi atas lingkungan fisik dan lingkungan sosial.

Lingkungan fisik yang diartikan dalam penelitian ini adalah adanya kebijakan program pupuk subsidi dan alsintan yang mengalami beberapa perbaikan sistem. Pada sektor program pupuk subsidi beberapa perbaikan sistem diantaranya perombakan pengajuan pupuk subsidi berbasis manual menjadi sistem online dan mulai diintegrasikan penggunaan Kartu Tani dalam penebusan pupuk subsidi. Perbaikan sistem juga dilakukan di sektor program alat mesin pertanian. Perbaikan sistem tersebut diantaranya mulai diintegrasikan pemberian program alsintan terhadap penumbuhan UPJA di setiap wilayah. Semua perbaikan-perbaikan sistem baik dari sektor pupuk subsidi dan sektor alat mesin pertanian diupayakan sesuai dengan harapan petani dan memudahkan petani dalam melakukan pekerjaannya sehari-hari.

Selain dari aspek lingkungan fisik, lingkungan sosial berupa sosialisasi yang baik dari penyuluh juga memengaruhi minat petani untuk mempelajari mekanisme program bantuan yang turun. Dari munculnya minat petani kemudian memunculkan harapan yang besar akan kontribusi program bantuan pada pekerjaannya. (Tasmara, 2002) memaparkan bahwa etos kerja menunjukkan harapan yang sangat dahsyat di hati individu sehingga menyedot seluruh perhatiannya untuk memenuhi harapan tersebut. Hasil penelitian (Rafita et al., 2013) memaparkan bahwasanya kebijakan yang ditetapkan oleh pemerintah daerah berupa kebijakan wajib shalat berjamaah berpengaruh positif terhadap etos kerja. Dengan demikian dapat disimpulkan bahwa etos kerja petani secara simultan dapat dipengaruhi oleh kebijakan program bantuan pemerintah.

\section{Uji Statistik t}

Uji statistik t digunakan untuk menunjukkan seberapa besar pengaruh satu variabel independen secara individual terhadap variabel dependen (Ghozali, 2011). Dasar pengambilan keputusan yaitu apabila nilai sig $<0,05$ maka $\mathrm{H}_{0}$ ditolak dan $\mathrm{H}_{1}$ diterima. Cara kedua adalah apabila nilai $t_{\text {hitung }}>\mathrm{t}_{\text {tabel }}$ maka $\mathrm{H}_{0}$ ditolak dan $\mathrm{H}_{1}$ diterima (Sujarweni, 2015). Hasil uji statistik t disajikan pada Tabel 6.

Tabel 6 Uji Statistik t

\begin{tabular}{|c|c|c|c|c|c|c|c|}
\hline \multicolumn{8}{|c|}{ Coefficients $^{\mathbf{a}}$} \\
\hline \multirow{2}{*}{ Model } & \multicolumn{2}{|c|}{$\begin{array}{l}\text { Unstandardized } \\
\text { Coefficients }\end{array}$} & \multirow{3}{*}{$\begin{array}{c}\text { Standardized } \\
\text { Coefficients } \\
\text { Beta }\end{array}$} & \multirow{2}{*}{$\mathbf{t}$} & \multirow{2}{*}{ Sig. } & \multicolumn{2}{|c|}{$\begin{array}{c}\text { Collinearity } \\
\text { Statistics }\end{array}$} \\
\hline & B & $\begin{array}{l}\text { Std. } \\
\text { Error }\end{array}$ & & & & $\begin{array}{c}\text { Toleranc } \\
\text { e }\end{array}$ & VIF \\
\hline (Constant) & 37.684 & 3.259 & & 11.563 & .000 & & \\
\hline $\begin{array}{l}\text { Tepat Kebijakan } \\
\text { Program Alsintan }\end{array}$ & .084 & .265 & .032 & .316 & .753 & .885 & 1.130 \\
\hline $\begin{array}{l}\text { Tepat Pelaksanaan } \\
\text { Program Alsintan }\end{array}$ & .413 & .272 & .150 & 1.522 & .132 & .917 & 1.090 \\
\hline $\begin{array}{l}\text { Tepat Target } \\
\text { Program Alsintan }\end{array}$ & .703 & .399 & .203 & 1.762 & .082 & .674 & 1.484 \\
\hline $\begin{array}{l}1 \text { Tepat Lingkungan } \\
\text { Program Alsintan }\end{array}$ & -.327 & .354 & -.108 & -.924 & .358 & .656 & 1.525 \\
\hline Tepat Kebijakan & & & & & & & \\
\hline $\begin{array}{l}\text { Program Pupuk } \\
\text { Subsidi }\end{array}$ & .245 & .355 & .072 & .689 & .493 & .828 & 1.208 \\
\hline $\begin{array}{l}\text { Tepat Pelaksanaan } \\
\text { Program Pupuk } \\
\text { Subsidi }\end{array}$ & .836 & .312 & .277 & 2.681 & .009 & .836 & 1.196 \\
\hline
\end{tabular}


Tepat Target

Program Pupuk

.506

.437

.125

1.159

.250

.773

1.294

Subsidi

Tepat Lingkungan

Program Pupuk

.333

.291

.128

1.145

.256

.719

1.390

Subsidi

a. Dependent Variable: Etos Kerja

Hasil Uji Statistik t pada Tabel 6 menunjukkan bahwa dari aspek eksternal petani dalam penelitian ini, hanya indikator Tepat Pelaksanaan Program Pupuk Subsidi yang memiliki pengaruh signifikan terhadap tingkat etos kerja petani. Pernyataan tersebut dapat dilihat dari nilai signifikansi sebesar 0,009 (sig < 0,05) dan nilai $\mathrm{t}_{\text {hitung }}$ sebesar 2,681 ( $\left.\mathrm{t}_{\text {hitung }}>2,000\right)$.

Hal ini dapat disebabkan karena pelaksanaan Program Pupuk Subsidi di Desa Ngadisuko telah memenuhi aturan dari Dinas Pertanian Kabupaten Trenggalek. Untuk indikator pengukuran keberhasilan pelaksanaan Program Pupuk Subsidi dalam penelitian ini dilihat dari waktu penebusan pupuk subsidi yang dapat dilakukan oleh petani tepat mendekati masa tanam yaitu 1-3 hari sebelum masa tanam. Dengan ketepatan waktu penebusan pupuk subsidi mampu mempengaruhi tingkat etos kerja petani di Desa Ngadisuko.

Hasil temuan lapangan juga sesuai dengan penelitian (Nugroho et al., 2018) yang memaparkan bahwa sebanyak 66,67\% responden menyatakan bahwa waktu penebusan pupuk subsidi sesuai dengan kebutuhan petani yaitu mendekati masa tanam. Dalam penelitian (Nugroho et al., 2018) juga memaparkan bahwa indikator Tepat Waktu dalam program pupuk subsidi di wilayah Daerah Istimewa Yogyakarta sudah efektif.

(Chakim et al., 2019) yang memaparkan bahwa nilai indikator Tepat Waktu dalam efektivitas Program Pupuk Subsidi memiliki nilai tertinggi diantara indikator yang lain yaitu sebesar 64,0 dengan rata-rata efektivitas penyaluran pupuk subsidi di angka 60,1. Hal ini membuktukan bahwa pelaksanaan program pupuk subsidi di Indonesia telah sesuai dengan prosedur dan secara tidak langsung mampu memenuhi aspek internal yang dimiliki petani.

Indikator-indikator dalam Variabel Efektivitas Program Alsintan semuanya tidak memiliki pengaruh yang signifikan terhadap tingkat etos kerja petani di Desa Ngadisuko. Dilihat dari indikator Tepat Kebijakan Program Alsintan menunjukkan bahwa indikator ini tidak memiliki pengaruh signifikan terhadap etos kerja petani. Pernyataan tersebut dapat dilihat dari nilai sig sebesar 0,753 (sig $>0,05)$ dan nilai $t_{\text {hitung }}$ sebesar 0,316 ( $\mathrm{t}_{\text {hitung }}<2,000$ ). Hal ini disebabkan karena bantuan alat mesin pertanian yang berhasil turun tidak sesuai dengan kebutuhan petani. Fakta di lapangan menunjukkan bahwa bantuan combain harvester kecil di Kelompok Tani Adi Luwih tidak dapat dimanfaatkan karena alat pemotong panen yang tidak dapat memotong hasil panenan padi secara maksimal. Selain itu mesin panen juga tidak dapat digunakan karena tidak cocok dengan agroekosistem di lahan petani. Maka dari itu petani tidak menggunakan alat mesin tersebut dan hanya disimpan di garasi rumah salah satu anggota Kelompok Tani Adi Luwih.

Hal ini sesuai dengan penelitian (Tarigan, 2019) yang memaparkan bahwa bantuan alat mesin pertanian berupa rice transplanter dan combain harvester tidak dapat digunakan di lahan petani. Hal ini dikarenakan ukuran alat mesin pertanian yang turun cukup besar dan tidak sesuai dengan kondisi lahan petani. Adapun bantuan alat mesin pertanian yang telah turun juga disimpan di Gudang kelompok tani.

Hasil penelitian (Nugroho et al., 2017) juga memaparkan bahwa beberapa bantuan alat mesin pertanian yang turun tidak tepat guna dikarenakan terdapat beberapa lahan di Kabupaten Wonosobo yang berbentuk terasering yang menyebabkan kesulitan dalam proses pemanfaatan alat mesin pertanian. Dari beberapa temuan di lapangan menunjukkan bahwa indikator Tepat Kebijakan Program Alsintan tidak berpengaruh signifikan terhadap etos kerja petani akibat adanya jenis bantuan alsintan yang tidak sesuai dengan kebutuhan petani di lapangan.

Dilihat dari indikator Tepat Pelaksanaan Program Alsintan dan Tepat Target Program Alsintan menunjukkan bahwa indikator ini tidak memiliki pengaruh signifikan terhadap etos kerja petani. Pernyataan tersebut dapat dilihat dari nilai signifikansi dari kedua indikator tersebut sebesar 0132 dan 
0,082 (Sig > 0,05) dan nilai $t_{\text {hitung }}$ sebesar 1,522 dan 1,762 (t hitung $\left._{2} 2,000\right)$. Hal ini disebabkan karena bantuan alat mesin pertanian yang turun tidak dapat dimanfaatkan secara merata oleh petani yang masuk sebagai keanggotaan kelompok tani yang aktif. Berikut ini pemaparan jumlah bantuan alat mesin pertanian yang berhasil turun berdasarkan Data Alsintan Kecamatan Durenan Tahun 2015 2018 dalam Tabel 7.

Tabel 7. Bantuan alat mesin pertanian di Desa Ngadisuko

\begin{tabular}{ll}
\hline \multicolumn{1}{c}{ Nama Kelompok Tani } & \multicolumn{1}{c}{ Bantuan Alsintan Yang Turun } \\
\hline \multirow{3}{*}{ Sumber Rejeki } & Traktor Roda 4 (1 unit) \\
& $\begin{array}{l}\text { Cronwn planter (1 unit) } \\
\text { Pompa air Niagara GT 6 - 1L (1 unit) } \\
\text { Tractor roda 2 (1 unit) }\end{array}$ \\
\hline \multirow{2}{*}{ Adi Luwih } & $\begin{array}{l}\text { Combain harvester kecil (1 unit) } \\
\text { Tractor roda 2 (1 unit) }\end{array}$ \\
\hline Langgeng Jaya & Tractor roda 2 (1 unit) \\
\hline
\end{tabular}

Jumlah bantuan alat mesin yang telah turun masih belum sepadan dengan jumlah petani penerima bantuan alsintan. Luasan lahan sawah petani di masing - masing kelompok tani rata-rata seluas 41 hektar. Dengan jumlah luasan lahan sawah seperti yang telah dipaparkan sebelumnya dan melihat ratarata kelompok tani hanya menerima bantuan traktor 2 sebanyak satu unit sangat jelas menunjukkan bahwa bantuan alat mesin pertanian di unit traktor roda 2 masih sangat kurang.

(Yunus et al., 2017) berasumsi bahwa lahan sawah dengan luasan 1 hektar dapat dikerjakan dengan estimasi waktu selama 8 jam. Dengan menganalisis kebutuhan mesin berdasarkan hasil penelitian (Yunus et al., 2017) memaparkan bahwa 1 bantuan traktor roda 2 yang dioperasikan di lahan Kelompok Tani Langgeng Jaya dengan waktu pengolahan per musim sebanyak 8 hari maka dapat ditemukan nilai efisiensi kerja mesin sebagai berikut :

$$
N=(T)\left\{\frac{P}{(D)(E)}\right\} \ldots \ldots \ldots(1)
$$

Keterangan:

$\mathrm{N}=$ Jumlah mesin (unit)

$\mathrm{T}=$ Waktu yang diperlukan untuk pengolahan per musim

$\mathrm{P}=$ Jumlah lahan yang diolah oleh traktor tangan $(\mathrm{Ha} / \mathrm{musim})$

$\mathrm{D}=$ Jam kerja operasi mesin (Jam)

$\mathrm{E}=$ Tingkat efisiensi kerja mesin $(\%)$

Dari hasil perhitungan rumus (1) didapatkan nilai efisiensi bantuan traktor roda 2 yang dioperasikan di Desa Ngadisuko sebesar $41 \%$. Apabila nilai efisiensi ditingkatkan menjadi 62,5\% sesuai dengan penelitian (Yunus et al., 2017) maka jumlah traktor yang dibutuhkan dapat dibutuhkan sebesar 67 unit. Apabila nilai efisiensi ditingkatkan menjadi $100 \%$ maka jumlah traktor yang dibutuhkan sebesar 41 unit dan jika ditingkatkan menjadi $200 \%$ maka jumlah traktor yang dibutuhkan sebesar 21 unit. Dengan berbagai perhitungan di atas membuktikan bahwa bantuan alat mesin pertanian unit traktor dirasa kurang memenuhi kebutuhan petani. Dari beberapa temuan di lapangan menunjukkan bahwa indikator Tepat Pelaksanaan Program Alsintan dan Tepat Target Program Alsintan tidak berpengaruh signifikan terhadap etos kerja petani dikarenakan jumlah bantuan alat mesin yang telah turun masih belum sepadan dengan jumlah petani penerima bantuan alsintan.

Dilihat dari indikator Tepat Lingkungan Program Alsintan menunjukkan bahwa indikator ini tidak memiliki pengaruh signifikan terhadap etos kerja petani. Pernyataan tersebut dapat dilihat dari nilai signifikansi sebesar 0,358 ( $\mathrm{sig}>0,05$ ) dan nilai thitung sebesar $-0,924$ ( $\mathrm{t}_{\text {hitung }}<2,000$ ). Hal ini disebabkan karena kegiatan perawatan dan evaluasi bantuan alat mesin pertanian di Desa Ngadisuko dirasa tidak dilakukan secara maksimal. Hal ini dikarenakan tidak adanya upaya monitoring lebih lanjut mengenai bantuan alat mesin pertanian yang telah turun.

Monitoring yang dilakukan oleh penyuluh pendamping adalah hanya memberikan laporan berbentuk dokumentasi penggunaan alat mesin pertanian yang turun beserta luasan lahan yang mampu diolah oleh bantuan alat mesin pertanian. Untuk perawatan bantuan kedepan diserahkan kepada kelompok. Pernyataan tersebut tidak sepenuhnya sesuai dengan (PSP, 2019b) yang memaparkan bahwasanya kegiatan evaluasi mengenai bantuan yang telah turun dilakukan oleh petugas pusat ataupun petugas 
lingkup provinsi/kabupaten/kota untuk mengetahui kondisi dan pemanfaatan alsintan serta masukan langsung terkait pemanfaatan alsintan yang telah turun.

Selain itu, tidak ada upaya relokasi alat mesin pertanian yang tidak dapat dimanfaatkan oleh kelompok ke daerah yg lebih membutuhkan. Hal ini menunjukkan bahwa proses evaluasi mengenai kebijakan bantuan alsintan dirasa kurang maksimal. Pernyataan diatas tidak sesuai dengan (PSP, 2019b) yang memaparkan bahwasanya dinas pertanian lingkup kabupaten/kota berhak memberikan surat peringatan kepada penerima bantuan alsintan apabila bantuan alsintan yang turun tidak secara optimal dalam pemanfaatannya. Selain itu, juga dinas pertanian juga berhak melakukan relokasi bantuan alsintan ke kelompok lain sama/antar kecamatan hingga relokasi antar kabupaten/kota.

Dari hasil temuan di lapangan menunjukkan bahwa indikator tepat lingkungan program alsintan tidak berpengaruh signifikan terhadap tingkat etos kerja petani karena masih belum optimalnya sistem monitoring dan upaya tindak lanjut dari pemerintah terhadap bantuan yang turun kepada petani.

Variabel Efektivitas Program Pupuk Subsidi hanya memiliki satu variabel saja yang berpengaruh signifikan terhadap tingkat etos kerja petani yang telah dijelaskan diatas. Dilihat dari indikator Tepat Kebijakan Program Pupuk Subsidi menunjukkan bahwa indikator ini tidak memiliki pengaruh signifikan terhadap etos kerja petani. Pernyataan tersebut dapat dilihat dari nilai signifikansi sebesar $0,493$ (sig $>0,05)$ dan nilai $t_{\text {hitung }}$ sebesar 0,689 ( thitung $_{\text {h }}<2,000$ ).

Hal ini disebabkan karena Jumlah pupuk subsidi yang turun dirasa oleh Sebagian besar petani di Desa Ngadisuko kurang dari kebutuhan pupuk anorganik yang digunakan di lahannya. Rata - rata jumlah pupuk subsidi yang turun hanya memenuhi sepertiga dari jumlah keseluruhan pupuk yang digunakan petani. Untuk melengkapi kekurangan konsumsi pupuk, solusi yang diambil oleh petani adalah dengan cara membeli pupuk non subsidi dengan harga yang sedikit lebih mahal daripada pupuk subsidi. Pernyataan tersebut sesuai dengan hasil penelitian (Kautsar et al., 2020) yang memaparkan bahwa mayoritas petani tidak menggunakan pupuk subsidi sesuai dengan anjuran. Petani menambahkan penggunaan pupuk non subsidi untuk memenuhi jumlah rekomendasi pupuk yang telah tertera dalam RDKK. Pernyataan ini didukung oleh (Nugroho et al., 2017) yang memaparkan bahwa kebijakan pupuk sudah banyak dilakukan penyempurnaan namun kondisi kelangkaan pupuk masih terjadi diakibatkan oleh pemakaian pupuk oleh petani yang melebihi dosis anjuran.

Dari hasil temuan di lapangan menunjukkan bahwa indikator tepat kebijakan program pupuk subsidi tidak berpengaruh signifikan terhadap tingkat etos kerja petani dikarenakan jumlah pupuk subsidi yang turun belum memenuhi kebutuhan petani di lapangan. Dilihat dari indikator Tepat Target Program Pupuk Subsidi menunjukkan bahwa indikator ini tidak memiliki pengaruh signifikan terhadap etos kerja petani. Pernyataan tersebut dapat dilihat dari nilai signifikansi sebesar 0,250 (sig > 0,05) dan nilai $t_{\text {hitung }}$ sebesar 1,159 ( $\mathrm{t}_{\text {hitung }}<2,000$ ). Hal ini disebabkan karena petani penerima program pupuk subsidi di Desa Ngadisuko telah sesuai dengan kriteria yang telah ditetapkan meliputi lahan sawah kurang dari $2 \mathrm{Ha}$, tercantum dalam e-RDKK dan memiliki Kartu Tani. Namun hal lain yang membuat indikator Tepat Target program pupuk subsidi tidak berpengaruh terhadap etos kerja petani adalah keterbatasan pengetahuan petani terkait implementasi Kartu Tani dalam penebusan pupuk subsidi

Temuan penelitian juga sejalan dengan hasil penelitian dari (Chakim et al., 2019) yang memaparkan bahwa indikator Ketepatan Sasaran Program memiliki nilai efektivitas $72 \%$ dalam kategori cukup efektif. Hal ini dikarenakan keterbatasan petani di Wilayah Kendal dalam penggunaan Kartu Tani serta penyediaan dana dalam rekening Kartu Tani yang membuat indikator Ketepatan Sasaran Program dalam kriteria efektivitas program pupuk subsidi tidak ercapai maksimal.

Dari hasil temuan di lapangan menunjukkan bahwa indikator tepat target program pupuk subsidi tidak berpengaruh signifikan terhadap tingkat etos kerja petani dikarenakan keterbatasan pengetahuan petani dalam penebusan pupuk subsidi dengan Kartu Tani. Dilihat dari indikator Tepat Lingkungan Program Pupuk Subsidi menunjukkan bahwa indikator ini tidak memiliki pengaruh signifikan terhadap etos kerja petani. Pernyataan tersebut dapat dilihat dari nilai signifikansi sebesar 0,256 (sig $>0,05)$ dan nilai $t_{\text {hitung }}$ sebesar 1,145 ( $\mathrm{t}_{\text {hitung }}<2000$ ).

Hal ini disebabkan karena kebanyakan petani di Desa Ngadisuko terkendala dengan teknologi yang ditawarkan melalui Kartu Tani. Mereka harus mengubah kebiasaan penebusan pupuk subsidi dari yang sebelumnya menggunakan uang tunai digantikan dengan Kartu tani. Selain itu opetani juga terkendala akan sistem top up saldo dalam Kartu Tani yang terlampau cukup susah dipraktikkan menurut petani 
di Ngadisuko. Masalah tersebut muncul diakibatkan sosialisasi program Kartu Tani baru muncul di Desa Ngadisuko pada Tahun 2017 dimana di daerah lain pada penelitian (Meliyanawati, Sumekar, 2020) yang memaparkan bahwa akhir Bulan Juli 2019 sebanyak 92,13\% petani di Jawa Tengah telah tercatat menerima dan menggunakan Kartu Tani. Hal ini menunjukkan bahwa proses sosialisasi program Kartu Tani di Desa Ngadisuko mengalami sedikit keterlambatan dibandingkan dengan wilayah lain.

Selain itu, masih ditemukan fakta bahwa petani tidak sepenuhnya memahami mekanisme program Kartu Tani yang menyebabkan rata-rata tanggapan mengenai program Kartu Tani hanya berhenti di tingkat cukup. Meskipun begitu, Desa Ngadisuko saat ini pada proses pengajuan program Kartu Tani dan telah menyelesaikan perekapan identitas petani ke website e-RDKK (Meliyanawati, Sumekar, 2020). Meliyanawati, Sumekar, 2020 juga memaparkan bahwa dengan adanya program Kartu Tani membuat petani merasa terbantu dengan adanya program tersebut namun masih terdapat kontra dalam benak petani mengenai kesulitan yang ditemui dalam penggunaan Kartu Tani. Dari hasil temuan di lapangan menunjukkan bahwa indikator tepat lingkungan program pupuk subsidi tidak berpengaruh signifikan terhadap tingkat etos kerja petani dikarenakan banyaknya petani yang memiliki persepsi negatif akan penggunaan Kartu Tani dalam penebusan pupuk subsidi.

\section{Koefisien Determinasi (R2)}

Koefisien determinasi $\left(\mathrm{R}^{2}\right)$ dilakukan untuk mengukur kemampuan model regresi dalam menjelaskan pengaruh variabel-variabel independen terhadap variabel dependen pada proporsi yang sama (Ghozali, 2011). Adapun dalam melihat nilai koefisien determinasi, Ghozali menganjurkan untuk melihat nilai Adjusted $\mathrm{R}^{2}$ dikarenakan nilai tersebut dapat menjelaskan bahwasanya pengaruh variabel independen bisa bernilai positif atau bernilai negatif. Adapun besarnya nilai adjusted $\mathrm{R}$ square disajikan pada Tabel 8.

Tabel 8. Uji koefisien determinasi

\begin{tabular}{lcccc}
\hline \multicolumn{5}{c}{ Model Summary } \\
\hline \multicolumn{4}{c}{$\mathrm{R}$} \\
Model & $\mathrm{R}$ & Square & Adjusted R Square & Std. Error of the Estimate \\
\hline 1 & $.526^{\mathrm{a}}$ & .277 & .205 & 3.691 \\
\hline a. Predictors: (Constant), Tepat Lingkungan Program Pupuk Subsidi, Tepat Target Program Pupuk Subsidi, Tepat \\
Kebijakan Program Alsinta, Tepat Pelaksanan Program Alsintan, Tepat Pelaksanaan Program Pupuk Subsidi, Tepat \\
Kebijakan Program Pupuk Subsidi, Tepat Target Program Alsintan, Tepat Lingkungan Program Alsintan
\end{tabular}

Berdasarkan Tabel 8 diketahui nilai adjusted $\mathrm{R}$ square sebesar 0,225 yang menunjukkan bahwa pengaruh variabel efektivitas pupuk subsidi dan efektivitas program alat mesin pertanian independen terhadap variabel etos kerja sebesar $22,5 \%$ dan sisanya dipengaruhi oleh faktor lain. Hal ini menunjukkan bahwa pengaruh variabel efektivitas pupuk subsidi dan alat mesin pertanian memberikan kontribusi yang rendah terhadap tingkat etos kerja petani di Desa Ngadisuko.

Hasil penelitian juga sejalan dengan penelitian (Shaleh et al., 2019) yang memaparkan bahwa bantuan pemerintah yaitu Program Bantuan Upaya Khusus Kedelai di Desa Jatiwaras, Tasikmalaya dikatakan belum efektif. Dari hasil GAP analisis antara nilai keseluruhan dimensi dan nilai tiap-tiap dimensi bernilai negative sebesar -2,7. Hal ini menunjukkan bahwa Program Bantuan Upaya Khusus Kedelai belum efektif. (Chakim et al., 2019) juga memaparkan bahwa penerapan Kartu Tani di Kendal dikatakan belum efektif. berada di tingkat tidak efektif. Hal ini dikarenakan dari nilai rata-rata respons sebesar 47,8\% dengan keterangan tidak efektif. (Chakim et al., 2019) memaparkan bahwa ketidakefektifan penerapan Kartu Tani dikarenakan petani yang kesusahan dalam menggunakan Kartu Tani dalam penebusan pupuk subsidi. Selain itu keterbatasan dana dalam sistem topup saldo dalam Kartu Tani yang menyebabkan penerapan Program Kartu Tani di Wilayah Kendal belum efektif.

(Chakim et al., 2019) juga memaparkan bahwa penerapan penyaluran pupuk subsidi di wilayah Kendal dikatakan belum efektif / berada di tingkat cukup efektif. Hal ini dikarenakan nilai rata-rata respons responden sebesar 60,1\% dengan keterangan cukup efektif. (Chakim et al., 2019) juga memaparkan bahwa beberapa faktor yang memengaruhi efektivitas penyaluran pupuk subsidi di Wilayah Kendal adalah jumlah pupuk subsidi yang belum sesuai dengan kebutuhan petani, sistem distribusi pupuk yang belum efisien serta harga pupuk yang dijual mendekati/melebihi Harga Eceran 
Tertinggi (HET). Dari banyaknya faktor yang belum terlaksana dengan sempurna menyebabkan tingkat efektivitas program prnyaluran pupuk subsidi di tingkat cukup efektif.

(Probowati, 2008) memaparkan bahwa aspek pengukuran etos kerja dapat diidentifikasi dengan munculnya minat dari individu untuk memenuhi kebutuhan biologisnya. (Suharyat, 2009) memaparkan bahwa aspek eksternal mampu memengaruhi minat seseorang dalam pemenuhan kebutuhan biologisnya. Dari hasil temuan di lapangan dan penelitian terdahulu dapat dibuktikan bahwa aspek eksternal petani dalam indikator Efektivitas Program Alsintan dan Program Pupuk Subsidi masih terdapat beberapa masalah sehingga memberikan pengaruh yang rendah terhadap tingkat etos kerja petani di Desa Ngadisuko.

\section{KESIMPULAN}

Kesimpulan yang dapat diambil dari penelitian ini adalah variabel efektivitas program alsintan dan pupuk subsidi secara simultan memiliki pengaruh terhadap etos kerja petani di Desa Ngadisuko dengan nilai signifikansi sebesar $0,00(0,00<0,05)$ dan nilai $F_{\text {hitung }}$ sebesar 3,874 $(3,874>3,11)$. Hal ini menunjukkan bahwa aspek etos kerja petani dapat dipengaruhi oleh faktor eksternal yaitu dari adanya program alsintan dan pupuk subsidi. Hasil penelitian ini juga sesuai dengan penelitian dari (Rafita et al., 2013) memaparkan bahwa kebijakan yang ditetapkan oleh pemerintah daerah berupa kebijakan wajib salat berjamaah berpengaruh positif terhadap etos kerja.

Hanya indikator tepat pelaksanaan program pupuk subsidi yang memiliki pengaruh secara parsial terhadap tingkat etos kerja petani di Desa Ngadisuko. Hal ini dikarenakan ketepatan waktu penebusan pupuk subsidi yang membuat tingkat etos kerja petani dapat dipengaruhi dari aspek eksternal yaitu indikator tepat pelaksanaan program pupuk subsidi. Seluruh indikator efektivitas program alsintan dan indikator tepat kebijakan, tepat target dan tepat lingkungan dalam program pupuk subsidi dikatakan tidak memiliki pengaruh secara parsial terhadap tingkat etos kerja petani. Hal ini dikarenakan masih banyak indikator yang telah dijelaskan diatas yang belum terlaksana secara sempurna.

Masalah dalam variabel efektivitas program alsintan yaitu bantuan alsintan yang turun tidak sesuai dengan kebutuhan petani, pemanfaatan bantuan alsintan yang tidak dapat dinikmati secara merata oleh petani penerima bantuan, tidak adanya monitoring lanjutan terkait bantuan alsintan yang turun dan upaya relokasi yang rendah untuk bantuan alsintan yang tidak tepat guna. Masalah dalam variabel program pupuk subsidi yaitu jumlah pupuk subsidi yang turun kurang dari kebutuhan petani, petani penerima bantuan yang merasa kesulitan dalam penggunaan Kartu Tani untuk penebusan pupuk subsidi dan persepsi negatif dari petani penerima bantuan dengan penggunaan Kartu Tani.

Banyaknya masalah yang belum terselesaikan secara parsial dalam variabel efektivitas program alsintan dan pupuk subsidi menyebabkan tingkat etos kerja petani tidak dapat dipengaruhi oleh indikator yang telah dijelaskan diatas.

Pengaruh variabel efektivitas program alsintan dan pupuk subsidi memberikan kontribusi yang rendah terhadap tingkat etos kerja petani hanya sebesar 22,5\%. Hal ini menunjukkan bahwa beberapa masalah dalam indikator Efektivitas Program Alsintan dan Program Pupuk Subsidi menyebabkan rendahnya nilai Adjusted R Square terhadap tingkat etos kerja petani di Desa Ngadisuko.

\section{DAFTAR PUSTAKA}

Andrias, A. A., Darusman, Y., \& Ramdan, M. (2017). Pengaruh Luas Lahan Terhadap Produksi dan Pendapatan Usahatani Padi Sawah. Jurnal Ilmiah Mahasiswa AGROINFO GALUH, 4(1), 521529.

Bappenas. (2019a). Peraturan Menteri PPN/Kepala Bappenas Nomor 5 Tahun 2019 tentang Tata Cara Penyusunan Rencana Strategis Kementerian/Lembaga Tahun 2020-2024.

Bappenas. (2019b). Rancangan Teknokratik Rencana Pembangunan Jangka Menengah Nasional 2020 - 2024: Indonesia Berpenghasilan Menengah - Tinggi Yang Sejahtera, Adil, dan Berkesinambungan. Kementerian PPN/ Bappenas. https://doi.org/10.1017/CBO9781107 415324.004

BPS. (2019). Kecamatan Durenan dalam Angka 2019. https://trenggalekkab.bps.go.id/publication /2019/09/26/0254d9650899d93fefa90465/kecamatan-durenan-dalam-angka-2019 
BPS RI. (2018). Indikator Kesejahteraan Rakyat.

Chakim, L., Rifin, A., \& Sanim, B. (2019). Pengaruh Implementasi Kartu Tani terhadap Efektivitas Penyaluran Pupuk Bersubsidi di Kabupaten Kendal, Jawa Tengah.

Dwiandana Putri, A., \& Setiawina, D. (2013). Pengaruh Umur, Pendidikan, Pekerjaan Terhadap Pendapatan Rumah Tangga Miskin Di Desa Bebandem. E-Jurnal Ekonomi Pembangunan Universitas Udayana, 2(4), 173-180.

Ghozali, I. (2011). Aplikasi Analisis Multivariate Dengan Program IBM SPSS 19 (edisi kelima). In Aplikasi Analisis Multivariate dengan program SPSS. https://doi.org/10.9744/jmk.10.2.pp. 124135

Ginting, E. (2004). Transformasi Sumberdaya Manusia Menuju Terwujudnya Masyarakat Mandiri dalam Pembangunan Masyarakat Mandiri. Prosiding Seminar Lokakarya Nasional, Ilmu Penyuluhan Pembangunan IPB.

Iskandar, O. (2002). Etos Kerja, Motivasi, Dan Sikap Inovatif Terhadap Produktivitas Petani. Makara Human Behavior Studies in Asia, 6(1), 26. https://doi.org/10.7454/mssh.v6i1.28

Jorgi, R. S., Gayatri, S., \& Dalmiyatun, T. (2019). Hubungan Tingkat Pengetahuan Petani dengan Efektivitas Pelaksanaan Program Kartu Tani di Kabupaten Semarang. AGRARIS: Journal of Agribusiness and Rural Development Research, 5(2). https://doi.org/10.18196/agr.5278

Karauwan, R., \& Mintardjo, V. P. K. L. C. (2015). Pengaruh Etos Kerja, Budaya Organisasi, Dan Beban Kerja Terhadap Kinerja Pegawai Di Dinas Pekerjaan Umum Minahasa Selatan. Jurnal Riset Ekonomi, Manajemen, Bisnis Dan Akuntansi.

Kautsar, M. R., Sofyan, \& Makmur, T. (2020). Analisis Kelangkaan Pupuk Bersubsidi dan Pengaruhnya terhadap Produktivitas Padi (Oryza sativa) di Kecamatan Montasik Kabupaten Aceh Besar. Jurnal Ilmiah Mahasiswa Pertanian, 5, 97-107.

Meliyanawati, Sumekar, T. D. (2020). Sikap dan Motivasi Petani Tanaman Padi terhadap Adopsi Program Kartu Tani di Kabupaten Grobogan. Jurnal Sosial Ekonomi Dan Kebijakan Pertanian, 4(1), 162-175. https://doi.org/http://dx.doi.org/10.21107/agriekonomika.v6i1.1895

Nugroho, A. D., Utami, S. N. H., Yuslianti, Y., Nurrokhmah, L., Al Huda, M. A., Suryani, L., Riyadi, I., Ulfaizah, U., Septijono, T., \& Adhini, H. A. N. (2017). Pelaksanaan Program Upaya Khusus (UPSUS) Swasembada Pangan di Kabupaten Wonosobo Provinsi Jawa Tengah. Jurnal Pengabdian Kepada Masyarakat (Indonesian Journal of Community Engagement). https://doi.org/10.22146/jpkm.27345

Nugroho, A. D., Siregar, A. P., Andannari, E., Shafiyudin, Y., \& Julia, I. C. (2018). Distribusi Pupuk Bersubsidi di Kabupaten Bantul Provinsi Daerah Istimewa Yogyakarta. 2(1), 70-82.

Nugroho, R. (2008). Public Policy: Teori Kebijakan, Analisis Kebijakan, Proses Kebijakan, Perumusan, Implementasi, Evaluasi, Revisi, Risk Management dalam Kebijakan Publik, Kebijakan sebagai Fifth Estate, Metode Penelitian Kebijakan. In Jakarta: Elex Media Komputindo. https://doi.org/10.1017/S0033291702006190

Perdana, A. S. (2013). Optimalisasi Etos Kerja Petani Sedulur Sikep sebagai Upaya Penanggulangan Krisis Pangan. Master of Science Penyuluhan Dan Komunikasi Pembangunan, 12(3), 215-224.

Probowati, A. (2008). Membangun Sikap dan Etos Kerja. Jurnal Managemen Dan Bisnis, 1, 22-24.

PSP, D. (2019a). Pedoman Teknis Pelaksanaan Penyediaan dan Penyaluran Pupuk Bersubsidi TA 2019.https://psp.pertanian.go.id/wpcontent/uploads/2020/04/Pedoman_Teknis_Penyediaaan_da n_Penyaluran_Pupuk_Bersubsidi_Tahun_2019.pdf

PSP, D. (2019b). Pedoman Teknis Pengadaan dan Penyaluran Bantuan Alat Mesin Pertanian. 48. https://psp.pertanian.go.id/wp-content/uploads/2019/01/Pedoman-Teknis-Pengadaan-danPenyaluran-Bantuan-Alat-dan-Mesin-Pertanian-Tahun-2019.pdf

PSP, D. (2019c). Rancangan Rencana Strategis Direktorat Jenderal Prasarana dan Sarana Pertanian 2020-2024. https://psp.pertanian.go.id/2020/06/rancangan-rencana-strategis-ta-2020-2024/

Purwantini, T. B., \& Susilowati, S. H. (2018). Dampak Penggunaan Alat Mesin Panen terhadap 
Kelembagaan Usaha Tani Padi. Analisis Kebijakan Pertanian, 16(1), 73. https://doi.org/10.21082/akp.v16n1.2018.73-88

Rafita, Y., Agustin, W. S., Adhiputra, R., \& Wulandya, S. A. (2013). PENGARUH KEBIJAKAN WAJIB SALAT BERJAMAAH TERHADAP ETOS KERJA PEGAWAI DAERAH KABUPATEN ROKAN HULU. Khazanah. https://doi.org/10.20885/khazanah.vol6.iss1.art6

Sa'diyah, R. (2017). Pentingnya Melatih Kemandirian Anak. Jurnal KORDINAT.

Shaleh, S. M., Noor, T. I., Sulistyowati, L., \& Setiawan, I. (2019). Efektivitas Bantuan Pemerintah (Suatu Kasus Program Upaya Khusus Pajale Penyediaan Sarana Kedelai Desa Jatiwaras, Kecamatan Jatiwaras, Kabupaten Tasikmalaya, Jawa Barat). 262-277.

Sinamo, J. (2011). Etos Kerja Profesional. Institut Darma Mahardika.

Suharyat, Y. (2009). Hubungan Antara Sikap, Minat dan Perilaku. Komunikasi Massa Dan Efek Media Terhadap Individu.

Sujarweni, V. W. (2015). SPSS untuk Penelitian. Pustaka Baru Press.

Tarigan, H. (2019). MEKANISASI PERTANIAN DAN PENGEMBANGAN USAHA PELAYANAN JASA ALSINTAN ( UPJA ) Agricultural Mechanization and Agricultural Machinery Services Business ( UPJA ) Development. 36(2), 117-128.

Tasmara, K. H. T. (2002). Membudayakan Etos Kerja Islami. Gema Insani Press.

Todaro, M. P. (1994). Pembangunan Ekonomi di Dunia Ketiga Edisi keempat Jilid I. In Economic Development. https://doi.org/2003

UU No 11 Tahun 2009, T. K. S. (2009). Undang-Undang Republik Indonesia No.11 Tahun 2009 tentang Kesejahteraan Sosial. Undang-Undang No.11 Tahun 2009

UU No 13 Tahun 2003, T. T. K. (2003). Undang-Undang Republik Indonesia No.13 Tahun 2003 tentang Ketenagakerjaan. Undang-Undang No.13 Tahun 2003

Yunus, L., Iswandi, M., \& Hasan, I. (2017). OPTIMALISASI KEBUTUHAN TRAKTOR UNTUK PENGOLAHAN TANAH SAWAH DI KECAMATAN WUNDULAKO KABUPATEN KOLAKA. Jurnal Sosio Agribisnis. https://doi.org/10.33772/jsa.v1i1.1833 